\title{
EFFECT OF ASCORBIC ACID, BENZYL ADENINE AND PACLOBUTRAZOL ON GROWTH, YIELD AND SOME METABOLIC CONSTITUENTS OF SUNFLOWER PLANTS
}

\author{
Emad EL- Dein A. Ewais, Abd El-Monem M. Sharaf, Esam A. Abd El-Azim, Mohamed \\ A. Ismail and Mohamed A. Amin \\ Botany and Microbiology Department, Faculty of Science, Al-Azhar University, Cairo, \\ Egypt.
}

\begin{abstract}
A field experiment was conducted to study the effect of foliar spray of ascorbic acid (50 and $100 \mathrm{ppm})$, benzyl adenine (50 and $100 \mathrm{ppm})$ and paclobutrazol (25 and $50 \mathrm{ppm}$ ) on growth, yield and some physiological parameters of (Helianthus annuus var. Sakha 53). Ascorbic acid was more effective than other treatments in enhancing growth parameters during stage I, while benzyl adenine was most effective during stage II. Paclobutrazol seemed to be less effective regarding growth characteristics. All doses applied tended to increase photosynthetic pigments, total soluble carbohydrates and soluble proteins of sunflower plants. The changes in proteolytic, amylolytic and lipolytic activities were also recorded. This was associated by improving yield quality and the nutritional value of the seeds. The effect of paclobutrazol was superior to that of ascorbic acid, benzyl adenine on increasing yield components. The highest lipid \% was recorded by $50 \mathrm{ppm}$ of ascorbic acid, whereas the highest carbohydrates and proteins of the yielded seeds were observed with plants treated with 100 ppm benzyl adenine.
\end{abstract}

\section{INTRODUCTION}

Sunflower (Helianthus annuus L.) is an important crop and ornamental plant in the world. It is used for animal feed and also it is the second most important crop producing edible oil after soybean (Shehata and El-Khawas, 2003; Fairless, 2007). Growth regulators and vitamins are known to affect plant growth through primary and secondary metabolism (Ewais et al.,2003; Reda et al., 2007). Rafique, et al. (2011) showed the best results on seedling growth, fresh and dry matter production of pumpkin seedlings due to $30 \mathrm{mg} \mathrm{L}^{-1}$ ascorbic acid treatments. Seedlings fresh weight, protein contents, protease and nitrate reductase activities were significantly affected by $30 \mathrm{mg} \mathrm{L}^{-1}$ ascorbic acid. Moreover, Mazher et al. (2011) found stimulatory effect of ascorbic acid (100 and $200 \mathrm{ppm}$ ) on all growth parameters (plant height, number of branches, number of leaves, stem diameter, root length as well as fresh and dry weights of all plant organs) of Codiaeum variegatum L. Several researchers, mentioned that benzyl adenine (BA) improve vegetative growth and yield quality, such as Mazrou (1992) on datura, Menesi et al. (1994) on Tagetes erecta, Zinna elegans and Celusia argentia, Farahat et al. (2002) on fennels, Vijay and Laxmi (2001) on mungbean, El-Abagy et al. (2003) on faba bean. El-Maadawy et al. (2006a) indicated that treating pot marigold plants with BA at $100 \mathrm{ppm}$ gave the highest number of inflorescences, which was significantly higher than the control in both seasons. Different benzyl adenine concentrations significantly increased inflorescence diameter, compared to control. Spraying plants with BA had also generally favourable effect on fresh and dry weight of inflorescences as compared to unsprayed plants. Zedan (2000) on Coriander and Zhang et al. (2006) on soybean observed that paclobutrazol treatments caused significant reductions in plant height, internodes length, leaf length and leaf area/plant, while dry weight per plant was increased. Zhang et al. (2006) on soybean observed that paclobutrazol treatments caused significant reductions in plant height, internodes length, leaf length and leaf area/plant, while dry weight per plant was increased. Therefore in the light of such findings, the present study was undertaken to investigate the effect of foliar application of 
ascorbic acid, benzyl adenine and paclobutrazol on growth, yield and biochemical constituents of sunflower plants grown under field conditions.

\section{MATERIALS AND METHODS}

Seeds of sunflower "Helianthus annuus" (Sakha 53) were obtained from Agricultural Research Centre, Ministry of Agriculture, Giza, Egypt. Uniform sunflower seeds were planted in natural loamy soil conditions in Botanical garden, Botany and Microbiology Dept., Fac. of Sci., Al- Azhar Univ., Nasr City, Cairo, Egypt, in a plot (4m width and 15m length) containing 7 ridges representing the following treatments: distilled water (as controls), Asc (50, $100 \mathrm{ppm}), \mathrm{BA}(50,100 \mathrm{ppm})$ and Pac $(25,50 \mathrm{ppm})$. The seeds were sown on one side of the ridge, with $20 \mathrm{~cm}$ apart between the hills. The developed plants were irrigated when ever required. Concentrations of the used plant growth regulators were chosen according to a preliminary experiment in which they caused a maximum germination percentage. The plants were sprayed twice with the above mentioned treatments. The first treatment was made when the age of plants was 33 days, while the second treatment was made when the age of plants was 65 days. The plant samples were collected for analysis when the plants were 40 (Stage I) and 72 (Stage II) days old. At the end of the growth season, analysis of the seeds yielded from the different treatments and the control were done. Contents of chlorophylls were estimated using the method of Vernon and Selly (1966). Contents of carotenoids were carried according to Lichtentahler (1981). Contents of soluble carbohydrates were measured according to the method of Umbriet et al. (1969). Contents of soluble proteins were estimated according to the methods of lowery $\boldsymbol{e t}$ al. (1951). Activities of amylases were determined using the method of Afifi $\boldsymbol{e t}$ al. (1986). Proteases activities were estimated using the method of Ong and Guacher (1972). Lipase activities were determined by method of Elwan et al. (1976). total lipids determined by using a soxhlet apparatus according to Guenther (1972). Statistical analysis of the obtained results was done using (L.S.D.) according to Snedecor and Cochran (1982).

\section{RESLTS AND DISCUSSION}

\section{1- Growth parameters:}

The obtained results (Tables $1 \& 2$ ) revealed that application of ascorbic acid or benzyl adenine at 50 and $100 \mathrm{ppm}$ created significant stimulative effects on growth parameters of sunflower plants. These effects were clear with the resulted induced increases in shoots and roots lengths; number of leaves/plant, fresh and dry weight of shoots and roots. Ascorbic acid was more effective than other treatments in enhancing growth parameters during stage I, while benzyl adenine was most effective during stage II. These findings are in accordance with Ewais (2003) reported that application of ascorbic acid improved growth and yield characteristics of broad bean plants. Recently, Rafique et al. (2011) found that the best results on seedling growth, fresh and dry matter production of pumpkin seedlings by 30 $\mathrm{mg} \mathrm{L}^{-1}$ ascorbic acid treatments. With respect to benzyl adenine, many investigators obtained similar positive effects on the growth of other plants such as mungbean (Vijay and Laxmi; 2001); faba bean (El-Abagy et al. 2003) marigold (El-Maadawy et al. 2006). Also, Ibrahim et al. (2010) found that foliar application of benzyl adenine (BA) at (50, 100 and $150 \mathrm{ppm}$ ) were significantly affected on croton plant height, number of branches and leaves/plant, root length, leaf area and fresh and dry weights of stem, leaves and roots. On the contrary, results shown in tables $1 \& 2$ revealed that growth characteristics were significantly lowered by paclobutrazol treatments. This was the case, with two exceptions, throughout the two stages of plant growth. The exceptional cases were represented by significant increases in shoot dry weight at stage I \& II in responses to paclobutrazol at 50 $\mathrm{ppm}$. These results are in agreement with those observed by Zedan (2000) on coriander and Zhang et al. (2006) on soybean. They reported that paclobutrazol treatments caused significant reductions in plant height, internodes length, leaf length and leaf area/plant, while dry weight per plant was increased. 
Table (1): Effect of ascorbic acid (Asc), benzyl adenine (BA) and paclobutrazol (Pac) on shoot length, root length and number of leaves of sunflower Helianthus annuus (var. Sakha 53) plants. Values given are means of ten replicates.

\begin{tabular}{|c|c|c|c|c|c|c|}
\hline \multirow{2}{*}{ Treatment (ppm) } & \multicolumn{2}{|c|}{ Shoot length $(\mathrm{cm})$} & \multicolumn{2}{c|}{ Root length $(\mathrm{cm})$} & \multicolumn{2}{c|}{ Number of leaves } \\
\cline { 2 - 7 } & Stage I & Stage II & Stage I & Stage II & Stage I & Stage II \\
\hline Control & 86.50 & 152.40 & 21.70 & 29.50 & 22.40 & 25.40 \\
\hline Asc 50 & 96.90 & 171.20 & 24.60 & 34.00 & 25.20 & 27.70 \\
\hline Asc 100 & 101.50 & 162.30 & 26.90 & 37.20 & 27.00 & 29.30 \\
\hline BA 50 & 92.30 & 187.70 & 23.80 & 35.60 & 25.10 & 30.20 \\
\hline BA 100 & 91.40 & 180.70 & 27.40 & 39.00 & 28.00 & 28.50 \\
\hline Pac 25 & 74.60 & 142.90 & 17.80 & 26.70 & 18.60 & 21.70 \\
\hline Pac 50 & 65.70 & 134.40 & 16.50 & 23.90 & 19.70 & 19.10 \\
\hline LSD at 0.05 & $\mathbf{1 . 5 5}$ & $\mathbf{4 . 6 1}$ & $\mathbf{0 . 7 1}$ & $\mathbf{0 . 8 7}$ & $\mathbf{0 . 6 8}$ & $\mathbf{0 . 5 8}$ \\
\hline
\end{tabular}

Table (2): Effect of ascorbic acid (Asc), benzyl adenine (BA) and paclobutrazol (Pac) on fresh weight and dry weight of shoots and roots of sunflower plants. Values given are means of ten replicates.

\begin{tabular}{|c|c|c|c|c|c|c|c|c|}
\hline \multirow{2}{*}{$\begin{array}{c}\text { Treatment } \\
\text { (ppm) }\end{array}$} & \multicolumn{2}{|c|}{ F.wt. of shoots (g.) } & \multicolumn{2}{c|}{ D.wt. of shoots (g.) } & \multicolumn{2}{c|}{ F.wt. of roots (g.) } & \multicolumn{2}{c|}{ D.wt. of roots (g.) } \\
\cline { 2 - 9 } Control & Stage I & Stage II & Stage I & Stage II & Stage I & Stage II & Stage I & Stage II \\
\hline Asc 50 & 340.30 & 633.30 & 30.08 & 62.43 & 43.20 & 54.50 & 6.25 & 7.44 \\
\hline Asc 100 & 345.66 & 693.20 & 34.20 & 98.29 & 42.20 & 133.56 & 6.46 & 29.05 \\
\hline BA 50 & 345.40 & 671.20 & 31.36 & 86.19 & 42.30 & 187.40 & 6.40 & 41.88 \\
\hline BA 100 & 331.80 & 784.10 & 32.67 & 100.54 & 35.70 & 207.80 & 6.43 & 52.58 \\
\hline Pac 25 & 176.50 & 333.50 & 17.73 & 51.70 & 23.70 & 61.50 & 2.60 & 10.78 \\
\hline Pac 50 & 305.20 & 545.30 & 32.20 & 88.04 & 45.80 & 114.50 & 5.95 & 5.95 \\
\hline $\begin{array}{c}\text { LSD at } \\
\text { 0.05 }\end{array}$ & $\mathbf{1 1 . 8 2}$ & $\mathbf{2 4 . 5 0}$ & $\mathbf{1 . 5 2}$ & $\mathbf{3 . 8 8}$ & $\mathbf{2 . 0 1}$ & $\mathbf{8 . 7 1}$ & $\mathbf{0 . 4 6}$ & $\mathbf{3 . 3 7}$ \\
\hline
\end{tabular}

\section{2- Photosynthetic Pigments:}

The contents of chlorophyll $a$; $b$; total chlorophyll $(a+b)$ and carotenoids of sunflower plants (Table 3) showed, in most cases, consistent and gradual increases in response to various treatments.

Table (3): Effect of ascorbic acid (Asc), benzyl adenine (BA) and paclobutrazol (Pac) on chlorophyll and carotenoids contents (mg/g. F. wt) of sunflower plants. Values given are means of three replicates.

\begin{tabular}{||c|c|c|c|c|c|c|c|c||}
\hline \multirow{2}{*}{ Treatment (ppm) } & \multicolumn{2}{|c|}{ Chlorophyll a } & \multicolumn{2}{c|}{ Chlorophyll b } & \multicolumn{2}{c|}{ Chlorophyll a+b } & \multicolumn{2}{c|}{ Carotenoids } \\
\cline { 2 - 9 } & Stage I & Stage II & Stage I & Stage II & Stage I & Stage II & Stage I & Stage II \\
\hline Control & 1.59 & 3.02 & 0.95 & 1.43 & 2.54 & 3.41 & 0.69 & 1.23 \\
\hline Asc 50 & 1.34 & 0.29 & 0.75 & 0.04 & 2.10 & 1.43 & 0.61 & 0.11 \\
\hline Asc 100 & 7.32 & 2.04 & 3.31 & 0.94 & 10.63 & 7.37 & 1.77 & 0.66 \\
\hline BA 50 & 2.39 & 3.67 & 1.22 & 1.93 & 3.61 & 4.41 & 1.07 & 1.41 \\
\hline BA 100 & 2.42 & 2.89 & 1.42 & 1.15 & 3.84 & 4.10 & 1.16 & 1.03 \\
\hline Pac 25 & 2.35 & 3.37 & 2.00 & 2.00 & 4.35 & 4.95 & 0.85 & 1.12 \\
\hline Pac 50 & 3.29 & 0.83 & 2.23 & 0.26 & 5.52 & 3.94 & 0.93 & 0.31 \\
\hline LSD at 0.05 & $\mathbf{0 . 1 0}$ & $\mathbf{0 . 1 2}$ & $\mathbf{0 . 0 6}$ & $\mathbf{0 . 1 3}$ & $\mathbf{0 . 0 6}$ & $\mathbf{0 . 1 2}$ & $\mathbf{0 . 0 5}$ & $\mathbf{0 . 0 6}$ \\
\hline
\end{tabular}

applied. Ascorbic acid at $100 \mathrm{ppm}$ was more effective followed by paclobutrazol at $50 \mathrm{ppm}$ than other treatments in enhancing chlorophyll contents, while benzyl adenine (at both doses) was more effective than other treatments in enhancing cartenoid content. The 
obtained results agree with those observed by a number of investigators (Hamza et al. 2007; El-Maadawy et al. 2006 and Abdel Aziz et al. 2009). Hamza et al. (2007) recorded that treating plants of Pelargonium zonale with paclobutrazol and cycocel significantly increased the total chlorophyll content when compared with the control treatment. El-Maadawy et al. (2006a) working on Calendula afficinalis L. plants, observed that BA (100) had a favorable effect on chlorophyll synthesis and accumulation in the leaves. Abdel Aziz et al. (2009) found that ascorbic acid at 100 ppm significantly increased chlorophyll a, b, a+b and carotenoids of gladiolus plants.

\section{3- Soluble Carbohydrates:}

Results of the present work (Table 4) revealed that total soluble carbohydrates contents of sunflower plants were tended to increase, with some exceptions, in response to the treatment with either ascorbic acid at $50 \mathrm{ppm}$ or benzyl adenine at $100 \mathrm{ppm}$. Application of paclobutrazol at $25 \mathrm{ppm}$ markedly increased total soluble carbohydrates contents in shoot at stage II and in fruits whereas, paclobutrazol at $50 \mathrm{ppm}$ significantly increased these contents in roots and shoots only at stage I as compared with the control. The highest increment in carbohydrates contents was observed in fruits as a consequence of applying 25 ppm of paclobutrazol and benzyl adenine at $50 \mathrm{ppm}$. On the other hand, ascorbic acid at 100 ppm tended to decrease total soluble carbohydrates contents in roots and shoots of sunflower plants. This was the case throughout the two stages of growth. Also, application of benzyl adenine and paclobutrazol (at both doses) significantly decreased these contents in roots during stage II. Concerning the fruits, data indicated that $100 \mathrm{ppm}$ of benzyl adenine or 50 ppm of paclobutrazol induced significant decreases in carbohydrates contents. In agreement with these results a number of investigators observed stimulating effect regarding the effect of ascorbic acid (Abdel Aziz et al. 2006; Farahat et al. 2007; Eid et al. 2010), benzyl adenine (Youssef, 2004) or paclobutrazol (Amin, 2007; Hamza et al. 2007) on carbohydrate contents. On the other hand, Elgayar (2004) revealed that treatment of soybean with benzyl adenine (25 and $50 \mathrm{ppm}$ ) resulted in slight effects on carbohydrate. On the contrary, ElAbagy et al. (2003) found that spraying faba bean plants with benzyl adenine (25 and 50 ppm) decreased carbohydrate percentage content.

Table (4): Effect of ascorbic acid (Asc), benzyl adenine (BA) and paclobutrazol(Pac) on total water soluble carbohydrates contents (mg/g. dry weight) of sunflower plants. Values given are means of three replicates.

\begin{tabular}{|c|c|c|c|c|c|}
\hline \hline \multirow{2}{*}{$\begin{array}{c}\text { Treatment } \\
(\mathrm{ppm})\end{array}$} & \multicolumn{2}{|c|}{ Roots } & \multicolumn{2}{c|}{ Shoots } & \multirow{2}{*}{ Fruits } \\
\cline { 2 - 5 } & Stage I & Stage II & Stage I & Stage II & \\
\hline Control & 37.20 & 60.96 & 20.23 & 72.57 & 161.53 \\
\hline Asc 50 & 103.14 & 68.47 & 56.08 & 130.61 & 165.98 \\
\hline Asc 100 & 34.10 & 37.70 & 18.54 & 60.15 & 170.23 \\
\hline BA 50 & 36.90 & 43.60 & 20.06 & 102.26 & 220.88 \\
\hline BA 100 & 77.78 & 43.64 & 42.29 & 142.76 & 135.94 \\
\hline Pac 25 & 27.85 & 42.30 & 15.15 & 91.07 & 322.64 \\
\hline Pac 50 & 92.99 & 35.13 & 50.56 & 66.67 & 54.18 \\
\hline LSD at 0.05 & $\mathbf{1 9 . 2 8}$ & $\mathbf{8 . 9 1}$ & $\mathbf{6 . 4 6}$ & $\mathbf{1 6 . 1 9}$ & $\mathbf{1 2 . 2 9}$ \\
\hline
\end{tabular}




\section{4- Soluble Proteins:}

In the present study, it was found (Table 5) that protein contents in shoots; roots as well as in the fruits of sunflower plants, mostly, were significantly increased in response to all applied doses of Asc, BA or Pac. The obtained results are in harmony with those reported by Abdel-Halim (1995) who observed that ascorbic acid increased protein content of wheat grains; El-Abagy et al. (2003) found that spraying faba bean plants with benzyl adenine significantly increased crude protein content and Wanas (2007) indicated that application of paclobutrazol considerably increased the levels of crude protein in leaves of treated faba bean plants compared with those of untreated ones.

Table (5): Effect of ascorbic acid (Asc), benzyl adenine (BA) and paclobutrazol (Pac) on soluble proteins contents $(\mathrm{mg} / \mathrm{g}$. dry weight) of sunflower plants. Values given are means of three replicates.

\begin{tabular}{|c|c|c|c|c|c|}
\hline \multirow{2}{*}{ Treatment $(\mathrm{ppm})$} & \multicolumn{2}{|c|}{ Roots } & \multicolumn{2}{c|}{ Shoots } & \multirow{2}{*}{ Fruits } \\
\cline { 2 - 5 } & Stage I & Stage II & Stage I & Stage II & \\
\hline Control & $122 . .97$ & 161.19 & 157.60 & 139.18 & 317.76 \\
\hline Asc 50 & 172.52 & 179.76 & 172.52 & 176.33 & 323.29 \\
\hline Asc 100 & 147.29 & 135.96 & 146.27 & 182.23 & 372.19 \\
\hline BA 50 & 206.60 & 258.94 & 269.67 & 274.29 & 347.02 \\
\hline BA 100 & 202.58 & 162.53 & 196.08 & 258.51 & 307.09 \\
\hline Pac 25 & 258.54 & 208.80 & 250.99 & 219.43 & 373.91 \\
\hline Pac 50 & 256.90 & 257.27 & 231.62 & 284.26 & 283.19 \\
\hline LSD at 0.05 & $\mathbf{2 4 . 4 8}$ & $\mathbf{2 3 . 2 9}$ & $\mathbf{1 5 . 1 2}$ & $\mathbf{1 2 . 7 0}$ & $\mathbf{1 4 . 0 3 6}$ \\
\hline
\end{tabular}

\section{5- Enzymes Activities:}

The obtained data (Table 6) indicated that both doses applied of ascorbic acid (Asc), benzyl adenine (BA) and paclobutrazol (Pac), with two exaptions, caused significant increase in the activities of proteases especially at stage I of growth. The exceptional cases were represented by significant decreases in proteases at stage I \& II in responses to BA at $100 \mathrm{ppm}$ and Asc at $50 \mathrm{ppm}$, respectively. The most proteases activities was recorded by BA at $100 \mathrm{ppm}$ (stage II), followed by Asc $100 \mathrm{ppm}$ (stage I). The stimulating effect of ascorbic acid on protease activity, obtained in the present study, are harmony with those observed by Rafique et al. (2011) who found that protease activity was higher in pumpkin seedling from seeds treated with $15 \mathrm{mgL}^{-1}$ Asc. Concerning the activities of amylases, results in table (6) indicated that foliar application of Asc, BA and Pac resulted, mostly, in either significantly reduced (at stage I) or significantly increased (at stage II). In this regard, Prusakova $\boldsymbol{e t}$ al. (2004) reported a similar view that the growth retarding activity of triazole compounds such as paclobutraz appears in the inhibition of amylase activity in barley (Hordium vulgare L.). Bialecka and Kepczynski (2003) found that BA at $10^{-5} \mathrm{M}$ had no effect on $\alpha$-amylase activity in Amaranthus caudatus seeds. It was also observed (Table 6) that $100 \mathrm{ppm}$ of Asc or $25 \mathrm{ppm}$ of Pac at both stageses (I \& II) of growth and $100 \mathrm{ppm}$ of BA or $50 \mathrm{ppm}$ of Pac at stage I significantly increased the lipolitic activities of sunflower plants. In the contrary, Asc at $50 \mathrm{ppm}$ (stages I \& II); BA at $50 \mathrm{ppm}$ (stage I) or Pac at $50 \mathrm{ppm}$ (stage II) caused a significant decreases of these activities. 
Table (6): Effect of ascorbic acid (Asc), benzyl adenine (BA) and paclobutrazol (Pac) on activities of proteases, amylases and lipases enzymes $(\mathrm{mg} / \mathrm{g}$. dry weight equivalent) of sunflower plants. Values given are means of three replicates.

\begin{tabular}{|c|c|c|c|c|c|c|}
\hline \multirow{2}{*}{$\begin{array}{c}\text { Treatment } \\
(\mathrm{ppm})\end{array}$} & \multicolumn{2}{|c|}{ Proteases } & \multicolumn{2}{c|}{ Amylases } & \multicolumn{2}{c|}{ Lipases } \\
\cline { 2 - 7 } & Stage I & Stage II & Stage I & Stage II & Stage I & Stage II \\
\hline Control & 1.46 & 1.43 & 1.69 & 1.12 & 14.06 & 11.72 \\
\hline Asc 50 & 1.66 & 1.28 & 1.40 & 1.96 & 9.37 & 9.37 \\
\hline Asc 100 & 2.36 & 1.44 & 1.43 & 1.69 & 29.68 & 14.84 \\
\hline BA 50 & 1.51 & 1.49 & 1.49 & 0.95 & 11.72 & 11.72 \\
\hline BA 100 & 1.44 & 2.50 & 1.16 & 1.48 & 25.00 & 11.72 \\
\hline Pac 25 & 1.68 & 1.40 & 1.57 & 1.11 & 24.21 & 2.34 \\
\hline Pac 50 & 1.76 & 1.85 & 1.69 & 1.27 & 18.75 & 9.37 \\
\hline LSD at 0.05 & $\mathbf{0 . 0 6 3}$ & $\mathbf{0 . 0 3 1}$ & $\mathbf{0 . 0 1 8}$ & $\mathbf{0 . 0 0 6}$ & $\mathbf{1 . 8 9}$ & $\mathbf{2 . 2 8}$ \\
\hline
\end{tabular}

\section{6- Yield components and nutritional value of the yielded seeds:}

Results recorded in table (7) indicated that foliar application of ascorbic acid (Asc), benzyl adenine (BA) and paclobutrazol (Pac) significantly increased yield components of sunflower plants. The highest value of all yield, mostly, were obtained with plants treated with Pac. The sequence of increase in diameter of head; weight of head; weigh of seeds/plant and weight of 100 seeds was as follows Pac > BA > Asc. The increments of weight of 100 seeds estimated by $39.46 \%, 33.76 \%$ and $26.80 \%$ in response to treating with Pac, BA and Asc, respectively compared with the control plants. The positive effect of Pac on yield components followed the negative trend obtained previously on vegetative growth. Thus, it could be stated that treatments of Pac had a beneficial effect on yield components. In this respect, Abdul Jaleel et al. (2007) reported that the application of Pac on Catharanthus roseus had significant effects on photosynthetic and anatomical responses thus can be used for improving productivity in medicinal plants. Moreover, Lolaei et al. (2012) reported that the highest leaf number, leaf area, petiole length, and total soluble solid percent were observed in control plants, while highest fruit number, fruit weight fruit, fruit set, flower number and yield of strawberry were obtained in plants treated with $90 \mathrm{mg} \mathrm{L}^{-1}$ Pac. They also mentioned that foliar application of Pac prior to flowering is recommended to increase the yield of strawberry. The obtained results (Table 8) showed that carbohydrates contents were found to be significantly increased only in response to applying BA at $100 \mathrm{ppm}$, while treatment the plants with either BA at $50 \mathrm{ppm}$ or Pac at $25 \mathrm{ppm}$ caused significant decrease in these contents of the seed yield. It was also observed (Table 8) that both doses applied of Asc, BA and Pac tended to significant increase both proteins contents and total lipids of the yielded seeds. The increases in the contents of carbohydrates and proteins of the see ds yield were shown to be the following order: BA > Pac > Asc. On the other hand, the sequence of total lipid \% was according to the following order: Asc > Pac > BA. In this regard, Vasudevan et al. (1996) reported that spraying three sunflower cultivars with cytokinins produced the highest seed oil content. Talaat and Youssef (1998) showed that oil in seeds of rosella plants were significantly increased as a result of BA application, especially at $40 \mathrm{mg} / \mathrm{L}$. Abed (2001) observed that BA significantly increased oil and protein $\%$ in seeds of cotton plants. Ibrahim et al. (2001) found that treatment of sunflower plants with kinetin $50 \mathrm{ppm}$ gave a significant increase in crude fat \%, respectively. Yousif et al. (2012) observed that $0.5 \mathrm{~g} \mathrm{l}^{-1}$ sucrose $+150 \mathrm{~g} \mathrm{l}^{-1}$ ascorbic acid increased fresh and dry weight, and total carbohydrates percentage in snapdragon cut spike flowers.

From the bulk of data obtained in the present investigation, it can be suggested that treatment of ascorbic acid, benzyl adenine and paclobutrazol had a beneficial effect on growth and chemical constituents as well as yield quality of sunflower plants. 
Table (7): Effect of ascorbic acid (Asc), benzyl adenine (BA) and paclobutrazol (Pac) on yield components of sunflower plants. Values given are means of ten replicates.

\begin{tabular}{|c|c|c|c|c|}
\hline Treatment (ppm) & $\begin{array}{c}\text { Diameter of } \\
\text { head }(\mathrm{cm})\end{array}$ & $\begin{array}{c}\text { Weight of head } \\
(\mathrm{g} .)\end{array}$ & $\begin{array}{c}\text { Weigh of } \\
\text { seeds/plant (g.) }\end{array}$ & $\begin{array}{c}\text { Weight of 100 } \\
\text { seeds (g.) }\end{array}$ \\
\hline Control & 12.07 & 72.14 & 47.15 & 4.15 \\
\hline Asc 50 & 17.67 & 114.38 & 58.98 & 5.43 \\
\hline Asc 100 & 16.30 & 104.84 & 64.89 & 5.91 \\
\hline BA 50 & 18.71 & 132.8 & 87.14 & 6.91 \\
\hline BA 100 & 16.38 & 126.43 & 95.66 & 5.62 \\
\hline Pac 25 & 18.43 & 145.90 & 112.48 & 6.47 \\
\hline Pac 50 & 18.22 & 146.38 & 100.74 & 7.24 \\
\hline $\begin{array}{c}\text { LSD at } \\
\text { 0.05 }\end{array}$ & $\mathbf{0 . 9 6}$ & $\mathbf{1 9 . 9 0}$ & $\mathbf{9 . 6 0}$ & $\mathbf{0 . 4 4}$ \\
\hline
\end{tabular}

Table (8): Effect of ascorbic acid (Asc), benzyl adenine (BA) and paclobutrazol (Pac) on soluble carbohydrates, proteins and total lipids of the seed yield of sunflower plants. Values given are means of three replicates.

\begin{tabular}{|c|c|c|c|}
\hline $\begin{array}{c}\text { Treatment } \\
(\mathrm{ppm})\end{array}$ & $\begin{array}{c}\text { Carbohydrates } \\
(\mathrm{mg} / \mathrm{g} . \mathrm{D} . \mathrm{wt})\end{array}$ & $\begin{array}{c}\text { Proteins } \\
(\mathrm{mg} / \mathrm{g} . \mathrm{D} . \mathrm{wt})\end{array}$ & Total lipids (\%) \\
\hline Control & 82.87 & 158.13 & 30.6 \\
\hline Asc 50 & 69.72 & 205.80 & 49.4 \\
\hline Asc 100 & 72.26 & 169.19 & 46.2 \\
\hline BA 50 & 59.33 & 209.23 & 38.4 \\
\hline BA 100 & 167.33 & 259.23 & 41.8 \\
\hline Pac 25 & 37.35 & 201.56 & 39.2 \\
\hline Pac 50 & 90.33 & 245.30 & 43.4 \\
\hline LSD at 0.05 & $\mathbf{1 3 . 3 9}$ & $\mathbf{1 8 . 1 3}$ & $\mathbf{3 . 7 2}$ \\
\hline
\end{tabular}

\section{REFERENCES}

Abd El-Aziz, N. G.; Mazher, A. A. M. and El-Habba, E. (2006): Effect of foliar spraying with ascorbic acid on growth and chemical constituents of Khya senegalensis grown under salt condition. American-Eurasian J.Agric.\& Environ .Sci., 1(3): 207214.

Abdel Aziz, N. G.; Taha, L. T. and Ibrahim, S. M. M. (2009): Some Studies on the Effect of Putrescine, Ascorbic Acid and Thiamine on Growth, Flowering and Some Chemical Constituents of Gladiolus Plants at Nubaria. Ozean Journal of Applied Sciences 2(2).

Abde l-Halim, S.M., (1995): Effect of some vitamins as growth regulators on growth, yield and endogenous hormones of tomato plants during winter. Egypt. J. of Appl. Sci., 10(12) 322-334.

Abdul- Jaleel, C.; Manivannan, P.; Sankar, B.; Kishorekumar, A.; Sankari, S. and Panneerselvam, R. (2007d): Paclobutrazol enhances photosynthesis and ajmalicine production in Catharanthus roseus. Process Biochemistry. 42: 1566-1570

Abed, A.M. (2001): Growth and yield of cotton plant as affected by pix, BA, Prep and their combinations. Annals of Agric. Sci., Moshtohor. Vol. 39(3):1551-1569.

Afifi, W.M.; Ahmed, M.I.; Moussa, Z.A. and Abd El-Hamid, M.F. (1986): Effect of gamma irradiation and $\mathrm{GA}_{3}$ on amylase activity of pea seedlings. Ann. Agric. Sci., Moshtohor. Vol. 24(4):2047-2057. 
Amin, A.A. (2007): Physiological response of two hybrids of yellow maize to foliar application of atonic and paclobutrazol. J. Agric. Sci., Mansoura Univ., 32(4): 2527-2541.

Bialecka, B. and Kepczynski, J. (2003): Regulation of $\alpha$-amylase activity in Amaranthus caudatus seeds by methyl Jasmonate, gibberellin, $\mathrm{GA}_{3}$ benzyl adenine and ethylene. Plant Growth Regulation, 39:51-56.

Eid, R. A.; Taha, S. L. and Ibrahim, M.M. S. (2010): Physiological properties studies on essential oil of Jasminum grandiflorum L. as affected by some vitamins. Ozean Journal of Applied Sciences 3(1).

El-Abagy, H.M.H.; Amin, A.A.; Rashad, E. M. and Hassanein M.S. (2003): Physiological response of some faba bean cultivars to foliar spray with benzyl adenine. Egypt. J. Appl. Sci.; 18(11B):563-579.

Elgayar, S.H. (2004): Effect of pendimethalin (stomp) and benzyl adenine (BA) on associated weeds, growth, yield and chemical composition of soybean plants at Nobarya. J. Agric. Sci. Mansoura Univ., 29(7), July, 3925-3934.

El-Maadawy, E.I.; Mansour, H.A. and Mostafa, H.G. (2006a): Response of annual flowering plants to manual pinching and benzyl adenine treatments : 1- Pot marigold (Calendula afficinalis L.) plants. J. Agric. Sci., Mansoura Univ., 31(7):4463-4483.

Elwan, S.H.; El-Naggar, M.R. and Ammar, M.S. (1976): Characteristics of lipases in the growth filtrate dialysate of Bacillus stearothermophilus grown at $55^{\circ} \mathrm{C}$ using a tribution cup. Plate assay. Bull. Fac. Sci. Riyadh Univ. "in press" (c.f. Ouda, A.E.S, 1977: studies on certain thermophilic bacteria. Ph.D. Thesis, Bot. Dep., Fac. Sci., Al-Azhar Univ., Cairo, Egypt.

Ewais, A, E. (2003): Physiological responses of broad bean plants to cadmium and lead and their antagonism by the antioxidant ascorbic acid and calcium. Journal of the Faculty of Education. No. 28.: 207-224.

Ewais, A.E.; Farghal, I.I. and Tobal, Y.F. (2003): Effect of Kinetin, riboflavin and zinc on gowth, flowering and biochemical constituents of Zinnia elegans and Celosia argentea plants. Journal of the Faculty of Education. No. 28: 189-205.

Fairless, D., (2007): Biofuel: the little shrub that could - maybe. Nature 449, 652-655.

Farahat, M.M.; Hebba, E.L. and Rashad, E. M. (2002): Physiological response of fennel to tryptophan, naphthalene acetic acid and benzyl adenine treatments in sandy soil. Egypt. J. Appl. Sci. 17(11) 624-633.

Farahat, M.M.; Ibrahim, S.M.M.; Taha, L.S. and El-Quesni, F.E.M. (2007): Response vegetative growth and some chemical constituents of Cupressus sempervirens L. to foliar application of ascorbic acid and zinc at Nubaria. World J.of Agric Sci., 3(3): 282-288.

Guenther, E. (1972): The essential oils. Vol. 1, Robert, E.; Kreiger Publishing Co. Huntington, New York.

Hamza, A.M.; Abd El-Kafie, O.M. and Mohei, A.M. (2007): Improving growth quality of Pelargonium zonale L. by using some growth retardants. J. Agric. Sci., Mansoura Univ., 32(10):8399-8411.

Ibrahim, S.I.; Sanaa, A.M.Z.; El-Shamey, I.Z. and Eisa, S.S. (2001): The effect of kinetin (kin) or thidiazuron (TDZ) in combinations with ABA or JA on regulating growth, yield and seed lipids composition of sunflower (Helianthus annuus L.). Annals Agric. Sci. (Cairo) 46(2):465-483.

Ibrahim, S.M; Taha, L.S.; Farahat, M.M. (2010): Vegetative Growth and Chemical Constituents of Croton Plants as Affected by Foliar Application of Benzyl adenine and Gibberellic Acid J Amer.Sci 6: 126- 130.

Lichtenthaler, HK. (1981): Photosynthesis IV. Philadelphia. Balaban Internat Science Service. p. 273-285. 
Lolaei, A.; Kaviani, B.; Raad, M., K.; Rezaei, M., A. and Maghsoudi, M. (2012): Effect of paclobutrazol and salinity on vegetative and sexual growth and fruit quality of strawberry (Fragaria $\times$ Ananassa Duch. cv. Selva). Annals of Biological Research, 3 (10):4663-4667.

Lowry, O.H.; Rosebrough, N.J.; Furr, A.I. and Randall, R.J. (1951): Protein measurement with folin phenol reagents. J. Biol. Chem. 193:265-275.

Mazher, A A.M.; Zaghloul, S. M. Mahmoud, S. A.; and Siam, H. S. (2011): Stimulatory Effect of Kinetin, Ascorbic acid and Glutamic Acid on Growth and Chemical Constituents of Codiaeum variegatum L. Plants. American-Eurasian J. Agric. \& Environ. Sci., 10 (3): 318-323.

Mazrou, M.M. (1992): The growth and tropine alkaloids distribution on the different organs of Datura innoxia, Mill Plants on relation to benzyl adenine (BA) application. Menofiya. J. Agric. Res. 17(4):1971-1983.

Menesi, F.A.; Khalafalla, M.M. and Kandeel, Y. (1994): Effect of some growth regulators and calcium chloride on Tagets erecta, L., Zinnia elegan, L. and Celalosia argenata, L. plants. The First Conf. of Ornamental Hort. (2) 418-425.

Ong, P.S. and Gaucher, G.M. (1972): Protease production by thermophillic fungi. Can. J. Microbiology, 19:129-133.

Prusakova, L.D.; Chizhova, S.I. and Pavlova, V.V. (2004): Assessment of triazole growth retarding activity in an $\alpha$-amylase bioassay using spring Barley endosperm. Russian J. of Plant Physiology, Vol. 51, No. 4, pp. 563-567. Translated from Fiziologiya rastenii, Vol. 51, No. 4, 2004, pp. 626-630.

Rafique, N.; Raza, S. H.; Qasim, M. and abd Iqbal, N. (2011): Pre-sowing application of ascorbhc acid and salicylic acid to seed of pnmpkin and seedling to salt. Pak. J. Bot., 43(6): 2677-2682.

Reda F.; Baroty, G.S.A.; Talaat, I.M.; Abdel-Rahim, I.A. and Ayad, H.S. (2007): Effect of some growth regulators and vitamins on essential oil, phenolic contents and activity of oxidoreductase enzymes of Thymus vukgaris L. World Journal of Agricultural Sciences 3 (5): 630-638.

Shehata, M.M.and El-Khawas, S.A., (2003): Effect of two biofertilizers on growth parameters, yield characters, nitrogenous components, nucleic acids content, minerals, oil content, protein profiles and DNA banding pattern of sunflower (Helianthus annus L. cv. Vedock) yield. Pak. J. Biol. Sci. 6, 1257-1268.

Snedecor, G.M. and Cochran, W.G. (1982): Statistical methods 7 edition, lowa state Univ., Press, Ames., thlowa U.S.A., pp: 325-330.

Talaat, I.M. and Youssef, A.A. (1998): Response of roselle plants (Hibiscus sabdariffa L.) to some growth regulating substances. Egypt J. Physiol. Sci., 22, No. 3, pp. 327338.

Umbriet, W.W.; R.H. Burris, J.F.; stauffer, P.P.;Cohen, W.J.; Johsen, L. G.A.; page, V.R.; and W.C. Schneicter, (1969): Manometric techniques, manual describing methods applicable to the studs of tissue metabolism. Burgess publishing Co., U.S.A., pp: 239.

Vernon, L.P. and Seely, G.R. (1966): The chlorophylls. Acad. Press, New York, London.

Vijay L. and Laxmi, V. (2001): Effect of benzyl adenine on dry matter distribution and yield of mungbean under different source sink relationship. Indian J. of Pulses; Res. 14(2):138-140.

Vasudevan, S.N.; Virupakshappa, K.; Bhaskar, S. and Udayakumar, M. (1996): Influence of growth regulators on some productive parameters and oil content sunflower (Helianthus annuus L.). Indian J. Plant Physiol. 1:277-280.

Wanas, A.L. (2007): Response of faba bean (Vicia faba, L.) plants to seed-treating with garlic extract, salicylic acid and paclobutrazol. J. Agric. Sci. Mansoura Univ., 32(2):971-990. 
Youssef, A.A.; Mahgoub, M.H. and Talat, I.M. (2004a): Physiological and biological aspects of Matthiola incana plants under the effect of putrescine and kinetin treatments. Egypt J. Appl. Sci.; 19(9B) 492-510.

Yousif A. A.; Sarfaraz F. A. and Hadar S. F. (2012): Effect of sucrose and ascorbic acid concentrations on vase life of snapdragon (Antirrhinum Majus L.) cut flowers. Int. J. Pure Appl. Sci. Technol., 13(2): 32-41.

Zedan, H.M. (2000): Effect of tryphan and paclobutrazol on carawy (Coriandrum sativum L.) plants. M.Sc. Thesis, Fac. Agric. Cairo Univ. Egypt.

Zhang, M.; Duan, L.; Zhai, J.; Li, X.; Tian, B.; Wang, Z.; He and Li, Z. (2006): Effect of plant growth regulators on water deficit - induced yield loss in soybean. Australian Agron. Conf. 10-15.

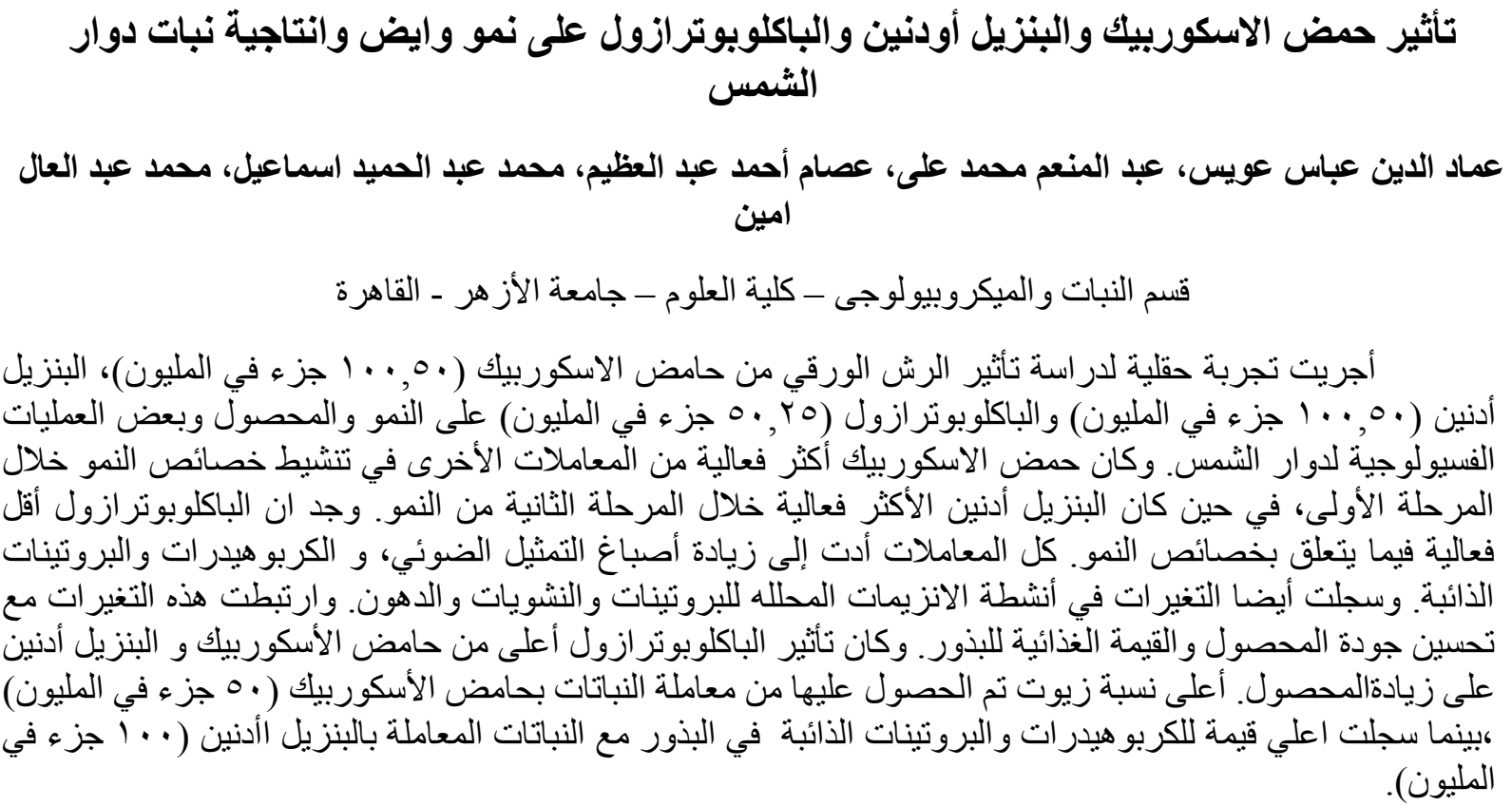

